\title{
IN-SERVICE TRAINING AT PRIMARY SCHOOL LEVEL: IMPACT ON CLASSROOM PRACTICES IN GUJARAT
}

\author{
MR. VISHWAJEET K. YADAV ${ }^{1} \&$ DR. MANDIRA SIKDAR ${ }^{2}$ \\ ${ }^{1}$ Lecturer, District Institute of Education and Training, Vadodara, Gujarat, India \\ ${ }^{2}$ Associate Professor \& PhD Programme Co-ordinator, Navrachana University, Vadodara
}

\begin{abstract}
Teacher Education includes both pre-service and in-service training to the teachers. Here, in the present Study, inservice training for teachers at primary and upper primary education level has been taken for research to know changes in Classroom Practices of primary Schools. Multi-stage random sampling techniques were followed for selection of sample. As the objective of the study was to assess effectiveness of in-service training for primary school teachers, the classroom teaching processes were observed through a Classroom Observation Schedule (CROS) from 25 (twenty-five) classes of teachers working in primary and upper primary schools. The analysis was based through simple percentage calculation on the activities of the teachers. The results show that in-service training has important positive effects for teachers, on the activities observed during the classroom teaching-learning process, continuous evaluation, use of teaching methods, use of teaching aids, use of audio-visual aids, end lesson evaluation and levels of teaching abilities of teachers observed.

KEYWORDS: In-Service Training; Classroom Practices; Primary Schools; Impact
\end{abstract}

Received: Feb 02, 2020; Accepted: Feb 22, 2020; Published: Feb 25, 2020; Paper Id.: IJMPERDFEB202098

\section{INTRODUCTION}

In-service teacher training updates teachers in issues concerning content, methodology and evaluation; upgrades serving teachers in tasks; initiates and orients to new roles and technologies, and provides opportunities. In-service teacher training programmes at primary education helps in building the capacity of and continuous professional development to primary teachers: and developing of theme based modules like NCF, RTE, SCE, and NISTHA, etc., for in-service teachers training at primary level.

The focus is on in-service teacher training programmes for primary school teachers in DIETs of Gujarat a State of India, where such programmes are conducted every year under the guidance of Gujarat Council of Educational Research and Training (GCERT), Government of Gujarat through an integrate scheme for Samagra Shiksha Abhyan, universalisation of primary education. Names of in-service training programmes are:

- Induction Programme: For inducting to newly recruited Head teachers;

- Vidya Sahayak: Induction training for newly recruited primary teachers.

- Diploma in Elementary Education: For upgrading untrained teachers by NIOS,

- Samarthya: To train teachers in pedagogical concept as well as content;

- School Readiness programme: To prepare teachers teaching at lower primary levels,

- Gunotsav 2.O: School monitoring Accreditation tool for SI of Schools. 
- School Heads: To train head of schools on new trends of education,

- Pragnya: To train teachers teaching at standards $1^{\text {st }}$ and $2^{\text {nd }}$ provide activity based pedagogy.

- Remedial Teaching: to enhance reading writing and numerical abilities of students.

- Innovative Practices: to encourage teachers conducting innovations, innovative ideas.

- Action Research: to train teachers conducting action researches in classroom problems.

- Content Based Training: to train competencies of teachers in their subjects. etc.

Among these programmes, hardspots are necessary in primary and upper primary. The primary level training is comprised of both content and theme based (RTE, NCF and SCE). These training programmes bring changes in classroom practices in schools regarding to core teaching abilities/skills. e.g., Management of activities, Use of inside and outside facilities for classroom teaching, Effective use of audio-visual aids, beginning of lesson with interesting activities, implement of quick reactions, conducting creative evaluation, clear instruction and suitable homework to students.

\section{Research Background:}

The Studies were reviewed by the researcher vividly with focus on their strengths and weaknesses.Yadav (NCERT-2012) conducted a Study at different States to assess impact of in-service teacher training in classroom transactions. The findings reported as in-service training had a positive impact on classroom transaction in terms of use of teaching skills, subject teaching, use of TLMs, development in teacher behaviors, curricular activities etc. Changes were observed in some States. The Study reports that impact depends on quality of in-service training and its transaction inputs.

A Study on in-service training as contributory factor influencing teachers' performance conducted by Jahangir, Saheen and Kazmi (2012) The present Study has brought a significant change in perception of the teacher. Eswaran and Singh (2008) (All India Primary Teachers' Federation) conducted a study on Effectiveness of In-service Education of Teachers on students drop out rate and effect of training on teachers' performance. It shows that in service training has positive impact on dropout rate and improvement of performance of teachers in classroom transaction. Chakraborty, Das, Bagchi, Upadhyay and Bandyopadhyay (2005) conducted a Study entitled “An Assessment of In-Service Teachers' Training Programmes in Five Districts of West Bengal". The Study finds that, they have not been as effective in orienting the teachers and the students social characteristics. A Study was conducted by Raina (2005) on opinion of secondary school teachers on the effectiveness of in-service training programmes in enhancing their professional competencies. The Study reported that the in-service training programmes were effective in developing professional competencies of teachers. Fifty one themes were listed in the questionnaire under the major areas. (viz., changes in the school curriculum, methods of evaluation, Knowledge in Educational Technology, Knowledge in Educational Psychology, Class Management and Developing Relationship with others, Motivating Teacher Performance, Developing Teacher Ethics, Leisure Utilization and Enhancing Job Satisfaction). It was reported that in-service training programmes were found to be not effective in the areas viz., knowledge in Educational Technology, Class Management and Enhancing Job Satisfaction. Joy in Manickam's (2002) survey of fifty primary school teachers. It is found that the teachers' attitude towards the use of computer became more favorable. The Study says that the contents are to be included more in the future in-service training programmes for the teachers. Subrahmanian (2001) conducted a Study on the impact of DIETs on the work efficiency of primary school teachers of Kerala. The Study assessed the work efficiency of teachers after undergoing in-service courses in DIETs with regard to content enrichment, class management, evaluation, and community participation. The Study says that in-service training programmes have positive impacts on the work efficiency of teachers in schools, to find the impact of in-service 
training being provided to the primary school teachers of Gujarat in terms of classroom transactions through conducting a study with the objective and research question cited below:-

\section{OBJECTIVE OF THE STUDY}

The objective of the study is as below:

1. To study the different components of the in-service training programmes conducted by DIETs of Gujarat in terms of changes in classroom practices as a result of such training.

\section{Research Question Pertaining to Objective:}

The research questions of the Study based on the objective :

- What are the opinions of teachers regarding training on classroom interaction?

- Whether in-service training programmes have any impact on the overall performance of the primary school teachers as a result of in-service training conducted for teachers?

\section{Core Teaching Abilities/Skills such as:}

- Activities during classroom,

- Use of teaching methods,

- Use of audio-visual aids,

- Beginning of lesson with interesting activities,

- Implement of quick reactions,

- Conducting creative evaluation,

- Clear instruction to students,

\section{METHODOLOGY}

The methodology includes design of the study; sample; tools used for collection of data; and techniques of data analysis which are as under:

\section{Design of the Study:}

The present study comes under the survey design of descriptive research. The findings of the study pertaining to the impact of in-service teacher training on classroom practices are mostly based on the observation of classroom processes of teachers.

\section{Sample:}

The study comprised of 25 (twenty-five) school teachers of Gujarat who received in-service training conducted by DIETs of Gujarat. For the purpose of this study classroom observation schedule (CROS) for teachers was developed and used. Twenty-five (25) CRCs spread over six (06) districts viz (Surat, Vadodara, Sabarkantha, Amreli, Rajkot and Kachh Bhuj) of Gujarat were selected for the purpose of following multi-stage sampling technique. In the present context, classroom teaching processes were observed from 25 (twenty-five) classes' teachers working in primary schools under these cluster 
resource centers.

\section{Tool Used:}

A Classroom Observation Schedule (CROS) was used to study different components of in-service training programmes for primary school teachers of Gujarat in terms of changes in classroom practices pertaining to core teaching abilities/skills e.g., Activities during classroom, Use of teaching methods, Use of audio-visual aids, Beginning of lesson with interesting activities, Implement of quick reactions, Conducting creative evaluation, clear instruction to students.

\section{Techniques of Data Analysis:}

The analysis was made through simple percentage calculation on the activities of the teachers were calculated to find percentages.

\section{RESULTS AND DISCUSSIONS}

The classroom practices of teachers were observed along a schedule, with reference to the aspects, core teaching abilities/skills e.g., Activities during classroom, Use of teaching methods, Use of audio-visual aids, beginning of lesson with interesting activities, Implementation of quick reactions, conducting creative evaluation, clear instruction to students, was presented as follows:

Table 1: Activities observed during the classroom teaching-learning process

\begin{tabular}{|l|l|l|l|}
\hline Sr. No & Activities & Yes & No \\
\hline 1 & Testing previous knowledge & $18(90 \%)$ & $2(10 \%)$ \\
\hline 2 & Classroom discipline & $20(100 \%)$ & 0 \\
\hline 3 & Activity oriented teaching & $18(90 \%)$ & $2(10 \%)$ \\
\hline 4 & Encouragement to students for discussion & $15(75 \%)$ & $5(25 \%)$ \\
\hline 5 & Students' participation in discussion & $16(80 \%)$ & $4(20 \%)$ \\
\hline 6 & Encouragement to students for asking questions & $11(55 \%)$ & $9(45 \%)$ \\
\hline 7 & Students' quick responses to questions & $14(70 \%)$ & $6(30 \%)$ \\
\hline 8 & Creative involvement of students in activities & $18(90 \%)$ & $2(10 \%)$ \\
\hline 9 & Explanation of concept with illustration & $18(90 \%)$ & $2(10 \%)$ \\
\hline 10 & Continuous evaluation during classroom teaching & $19(95 \%)$ & $1(5 \%)$ \\
\hline 11 & Use of textbook for description of content & $14(70 \%)$ & $6(30 \%)$ \\
\hline 12 & Use of teaching - learning methods & $20(100 \%)$ & 0 \\
\hline 13 & Use of teaching aids & $20(100 \%)$ & 0 \\
\hline 14 & Use of audio-visual aids & $14(70 \%)$ & $6(30 \%)$ \\
\hline 15 & End lesson evaluation of students & $20(100 \%)$ & 0 \\
\hline
\end{tabular}

From the table 1 it can be observed that out of 20 primary school classrooms observed, all the activities required for an effective classroom teaching-learning were observed throughout the teaching-learning process. The activities used by all the teachers in their classroom teaching were maintaining classroom discipline, use of teaching methods, use of teaching aids and end lesson evaluation.

Most of the teachers were using the activities of continuous evaluation throughout the lesson (95\%), creatively involving students in teaching-learning activities (90\%), activity oriented teaching (90\%), testing of previous knowledge (90\%), explanation of concept with illustration (90\%) and participating students in discussion (80\%). It was also observed 
that majority of the teachers were encouraging students for discussion (75\%), using textbook for content description (70\%), getting quick response to questions (70\%) and using audio-visual aids (70\%),

Table 2: Continuous evaluation during classroom teaching-learning process

\begin{tabular}{|l|l|l|l|}
\hline \multicolumn{1}{|c|}{ Sr. No } & \multicolumn{1}{|c|}{ Continuous evaluation } & Frequency & Percentage \\
\hline 1 & Through oral questioning & 15 & 75 \\
\hline 2 & Through written questions & 6 & 30 \\
\hline 3 & Through exercise or homework & 2 & 10 \\
\hline
\end{tabular}

From the table 2 it can be seen that majority of the teachers were continuously evaluating their students through oral questioning $(75 \%)$ whereas the remaining teachers were continuously evaluating their students through either written questions $(30 \%)$ or exercise/homework $(10 \%)$.

Table 3: Use of teaching methods in classroom teaching-learning process

\begin{tabular}{|l|l|l|l|}
\hline \multicolumn{1}{|c|}{ Sr. No } & \multicolumn{1}{|c|}{ Teaching methods } & Frequency & $\begin{array}{c}\text { Percentage } \\
(\%)\end{array}$ \\
\hline 1 & Lecture & 13 & 65 \\
\hline 2 & Role play & 2 & 10 \\
\hline 3 & Project work & 4 & 20 \\
\hline 4 & Team work/activity & 7 & 35 \\
\hline 5 & Practical work & 5 & 25 \\
\hline 6 & Field observation & 5 & 25 \\
\hline
\end{tabular}

From the table 3 it can be observed that out of 20 classrooms observed, the teaching method used by majority of the teachers was lecture (65\%). The other teaching methods used by the teachers were team work/activity (35\%), practical work (25\%), field observation (25\%), project work (20\%) and role play (10\%).

Table 4: Use of teaching aids in classroom teaching-learning process

\begin{tabular}{|l|l|l|l|}
\hline \multicolumn{1}{|c|}{ Sr. No } & \multicolumn{1}{|c|}{ Teaching aids } & Frequency & Percentage \\
\hline 1 & Chalkboard & 14 & 70 \\
\hline 2 & Chart & 9 & 45 \\
\hline 3 & Model & 9 & 45 \\
\hline 4 & Flash cards & 4 & 20 \\
\hline 5 & Worksheet & 4 & 20 \\
\hline 6 & Figure illustration & 7 & 35 \\
\hline
\end{tabular}

From the table 4 it can be seen that majority of the teachers was using chalkboard (70\%) as teaching aid. The remaining teaching aids used by the teachers were chart (45\%), model (45\%), figure illustration (35\%), flash cards $(20 \%)$ and worksheets $(20 \%)$.

Table 5: Use of audio-visual aids in classroom teaching-learning process

\begin{tabular}{|l|l|l|l|}
\hline \multicolumn{1}{|c|}{ Sr. No } & \multicolumn{1}{|c|}{ Audio-visual aids } & Frequency & Percentage \\
\hline 1 & LCD projector & 7 & 35 \\
\hline 2 & Television & 3 & 15 \\
\hline
\end{tabular}




\begin{tabular}{|l|l|l|l|}
\hline $\mathbf{3}$ & Computer & 6 & 30 \\
\hline $\mathbf{4}$ & Films/videos & $\mathbf{5}$ & $\mathbf{2 5}$ \\
\hline $\mathbf{5}$ & Mobile & $\mathbf{1}$ & $\mathbf{5}$ \\
\hline
\end{tabular}

From the table 5 it can be observed that some of the teachers were using audio-visual aids in their classroom teaching-learning process. The use of audio-visual aids such as LCD projector (35\%), computer (30\%), films/videos (25\%) and television (15\%) have been found during the classroom observation. It was also observed that one of the teacher used mobile as audio-visual aid during the classroom teaching.

Table 6: End lesson evaluation in classroom teaching-learning process

\begin{tabular}{|l|l|l|l|}
\hline \multicolumn{1}{|c|}{ Sr. No } & \multicolumn{1}{|c|}{ Continuous evaluation } & \multicolumn{1}{c|}{ Frequency } & Percentage \\
\hline 1 & Through oral questioning & 15 & 75 \\
\hline 2 & Through written questions & 9 & 45 \\
\hline 3 & Through exercise or homework & 4 & 20 \\
\hline
\end{tabular}

From the table 6 it can be seen that majority of the teachers had used oral questioning (70\%) for end lesson evaluation of their students whereas the remaining teachers used written questioning (45\%) and exercise/homework (20\%) for end lesson evaluation of their students.Further observation about the level of teaching abilities of teachers done, the following result presented in table 7 has been emerged out.

Table 7: Levels of teaching abilities of teachers

\begin{tabular}{|l|l|l|l|l|}
\hline \multicolumn{1}{|c|}{ Sr. No } & \multicolumn{1}{|c|}{ Teaching abilities } & \multicolumn{1}{c|}{ Satisfied } & \multicolumn{1}{c|}{ Average } & \multicolumn{1}{c|}{ Unsatisfied } \\
\hline 1 & Management of activities & $11(55 \%)$ & $9(45 \%)$ & 0 \\
\hline 2 & $\begin{array}{l}\text { Use of inside and outside facilities for classroom } \\
\text { teaching }\end{array}$ & $11(55 \%)$ & $4(20 \%)$ & $5(25 \%)$ \\
\hline 3 & Effective use of audio-visual aids & $9(45 \%)$ & $5(25 \%)$ & $6(30 \%)$ \\
\hline 4 & Beginning of lesson with interesting activities & $11(55 \%)$ & $7(35 \%)$ & $2(10 \%)$ \\
\hline 5 & Implement of quick reactions & $6(30 \%)$ & $11(55 \%)$ & $3(15 \%)$ \\
\hline 6 & Conducting creative evaluation & $11(55 \%)$ & $7(35 \%)$ & $2(10 \%)$ \\
\hline 7 & Conducting diagnostic work & $10(50 \%)$ & $9(45 \%)$ & $1(5 \%)$ \\
\hline 8 & Clear instruction to students & $15(75 \%)$ & $5(25 \%)$ & 0 \\
\hline 9 & Suitable homework to students & $14(70 \%)$ & $6(30 \%)$ & 0 \\
\hline
\end{tabular}

From the table 7 it can be observed that out of 20 classrooms observed, majority of the teachers had demonstrated satisfied level of their teaching abilities in providing clear instructions to students (75\%) and giving suitable homework to students (70\%). More than half of the teachers demonstrated satisfied level of their teaching abilities in managing activities $(55 \%)$, use of facilities in classroom (55\%), beginning of lesson with interesting activities (55\%), conducting creative evaluation (55\%), and an average level of teaching ability in implementing quick reactions of students (55\%). Half of the teachers $(50 \%)$ had demonstrated satisfied level of teaching abilities in conducting diagnostic work. 


\section{FINDINGS}

The findings from the above analysis based on classroom practices pertaining to impact of in-service training are as follows:

- The most of the teachers were using the activities of continuous evaluation throughout the lesson (95\%), creatively involving students in teaching-learning activities (90\%), activity oriented teaching (90\%), testing of previous knowledge (90\%), explanation of concept with illustration (90\%) and participating students in discussion $(80 \%)$.

- Majority of the teachers were continuously evaluating their students through oral questioning (75\%).

- $\quad$ Majority of the teachers was using lecture method (65\%).

- Majority of the teachers was using chalkboard (70\%) as teaching aid.

- Majority of the teachers had used oral questioning (70\%) for end lesson evaluation of their students.

- Majority of teachers indicated that in-service training has a significant effect on the abilities/skills of teachers for presenting the lesson in the classroom teaching-learning processes.

- Majority of the teachers had demonstrated satisfied level of their teaching abilities in the providing clear instructions to students (75\%) and giving suitable homework to students (70\%).

\section{REFERENCES}

1. Chakraborty, A., Das, B.K., Bagchi, B., Upadhyay, S. and Bandyopadhyay, d. 2005. An Assessment of in-service teachers' training programmes in five districts of west Bengal, institute of development studies Kolkata (for State Project Office) West Bengal, District Primary Education Programme.

2. Jahangir, S.F., Saheen, N. and Kazmi, S.F. (2012). In service training: a contributory factor influencing teachers' performance. International Journal of Academic Research in Progressive Education and Development. 1: (1).

3. MHRD (2011). Sarva Shiksha Abhiyan: Framework for implementation based on the Right of Children to Free and Compulsory Education Act, 2009. New Delhi: Department of School Education and Literacy, MHRD, Government of India.

4. NCERT,(2005). National curriculum framework, 2005. NCERT, New Delhi.

5. Raina, M.S.P. (2005). Opinion of secondary school teachers on the effectiveness of in-service training in enhancing professional competency. (Unpublished M.Ed. Dissertation). University of Calicut.

6. Subrahmanian, T. (2001). The impact of DIETs on the work efficiency of primary school teachers of Kerala state. (Doctoral Thesis). Department of Education. Calicut University.

7. Yadav, S.K. (2012). Impact of in-service teacher training on classroom transaction. (A set of four books). New Delhi: NCERT 

